\section{THE INVENTIONS EXHIBITION}

$\mathrm{T} N$ the presence of a crowded and distinguished assembly the Inventions Exhibition was opened by the Prince of Wales on Monday. The Exhibition is, as usual on first days, still in a somewhat chaotic condition, and we can do no more this week than refer to the leading incidents of the opening ceremony. Sir Frederick Bramwell, Chairman of the Executive Council, in his address to the Prince of Wales, gave a sketch of the progress and objects of the Exhibition, which, he pointed out, is intended to illustrate the progress of inventions since the year 1862 , and that of musical instruments and appliances since the commencement of the present century. The labours of the different committees were, he stated, rendered extremely onerous by the vast number of applications received-a number far greater then we had space to accommodate. Influential Commissions have been nominated by Austria-Hungary, France, China, Greece, Italy, Japan, Russia, Siam, and Switzerland, from which countries interesting and valuable exhibits have been received or are promised. Arrangements have been made with the Council of the Royal Albert Hall by which that building forms an integral portion of the Exhibition, with the National Fish Culture Association for the maintenance of the Aquarium, and with the Council of the Royal Horticultural Society for the holding of the usual periodical flower and fruit shows. The Old London Street, which was so popular a feature in last year's Exhibition, has been maintained. Many small annexes have been swept away, and in their places spacious galleries have been erected. Not only has greater exhibiting space been thus obtained, but the gardens, which are so great a source of attraction to visitors, have actually been enlarged. Notwithstanding the fact that the gallery used last year for machinery has been greatly extended to meet the requirements of exhibitors, it proved to be inadequate for the many important inventions for which motive power was desired; indeed, it has been found necessary to furnish such power in no less than three other galleries. "The employment of electricity for the purposes of lighting," Sir Frederick said, "is undoubtedly one of the most striking instances of the application of science to the purposes of daily life ; we have, therefore, not hesitated to give this subject special prominence. The method we have adopted will, it is believed, render any sudden failure of the lights impossible, and will favourably display the most recent and improved apparatus, and the advances that up to this date have been made in electric lighting. After most careful experiments we have ventured to employ, for the garden illumination, the incandescent electric lamp, and we have done so in a manner and on a scale which, we believe, has never before been attempted. As a division of the Exhibition is devoted to music, we have set apart an important portion of the buildings to the illustration of instruments and appliances appertaining to that art; and we have invited the formation of a historical loan collection of musical instruments, which we believe is of a deeply interesting character. In requesting your Royal Highness to declare this Exhibition open we desire to express the hope that it may, on the one hand, be the means of bringing valuable and meritorious inventions prominently before the general public, to the benefit and credit of the exhibitors, and that it may, on the other hand, be the means by which that public may, within the area of one exhibition, be enabled to appreciate the marvellous progress which during the past quarter of a century every industry has achieved."

The Prince of Wales, in reply said: It is with much pleasure that I have listened to the report of the Executive Council, and I fully appreciate the labours which you have bestowed upon this great undertaking. At the closing of the International Fisheries Exhibition I took the opportunity of expressing a hope that an International Inventions Exhibition might be held in these buildings during the present year; and I am sincerely gratified to find that this hope has been realised. The scope of this Exhibition is, indeed, vast, and I can readily comprehend the difficulties which must have beset you and the Committee of Advice in your endeavours to secure adequate representation for each branch of industry. I have observed with much pleasure that the classification originally adopted has been made the practical basis of the allotment of space in the Exhibition, and that the exhibits in each group have, as far as possible, been placed together. I am convinced that by following this plan you have materially increased the educational value of the Exhibition. I readily echo the sentiments of gratitude which you have expressed for the invaluable aid rendered by the guarantors; and I join with you in welcoming the representatives of those foreign countries who are present here to-day.

The Prince of Wales, after declaring the Exhibition open, made a tour of the galleries in company with the Princess of Wales and many others of the distinguished visitors who were present.

\section{THE FLORA OF BANK-NOTES}

"I A Flore des Billets de Banque" is the title of an article in Science et Nature, an article which, in spite of an amusing tendency inseparable from all things savouring of sensational science, may suggest thoughts more or less alarming in view of recent discoveries in bacteriology. It is no new fact that books, coins, and other articles of a durable nature which pass much from hand to hand may be the means of transmitting

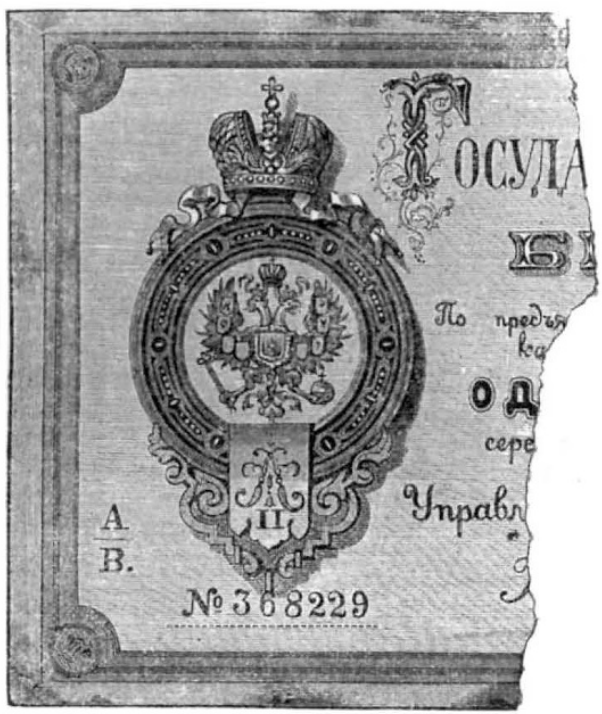

FIG. I

infectious diseases, and if these infectious diseases are caused by visible and tangible agents, it is not going far to expect that the agents should be discoverable on the transmitting media by means of the microscope, and by other methods employed by the specialists who devote themselves to tracing the awful bacterium to its home. Of course it is now matter of fact that "bacteria" (using the term in its widest sense) can be and are causal agents in disease, and the writer of the article referred to shows that bacteria and other minute organisms always occur on bank-notes ; there is, perhaps, no more in this observation than that it demonstrates a fact in a particular case 
which scientific biologists have shown to be true much more generally. All objects exposed to the air and passed from hand to hand are apt to have minute organisms settling upon them, and we should expect such things as bank-notes, which pass through many hands, to be favoured by more than their usual share of "germs," knowing that simple abrasion is no satisfactory means for removing such minute bodies. Nevertheless it is interesting to see what really have been found on European banknotes. M. Reinsch some time ago undertook to examine the money in circulation, with the result that two very small algæ, which were named as species of Chroococcus and Pleurococcus respectively, proved to be not uncommon on coins. M. Jules Schaarschmidt has since undertaken to examine the paper currency of various States, with the result that such living organisms and other objects as those in the annexed woodcut were discovered. According to the statements to hand, the notes examined were particularly those of Austro-Hungary and Russia, and new as well as old ones furnished " an abundant cryptogamic vegetation," as well as "microbes," and objects such as grains of starch, particles of hair, \&c.

The entire list comprises Bacterium termo, the common bacterium of putrefaction; Sacchuromyces cerevisia, the

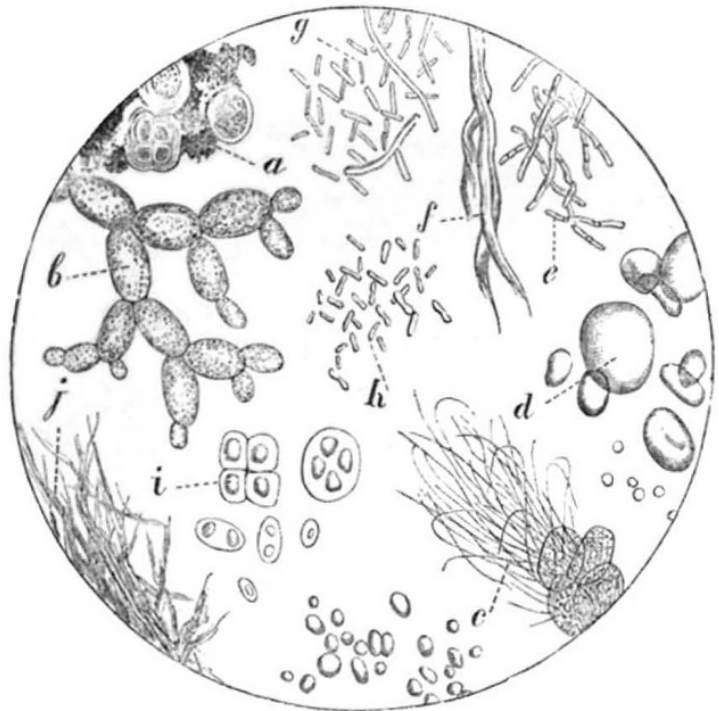

Fig. 2. $-a$ and $i$, minute algæ; $b$, yeast cells; $c$, Leptothrix; $d$, starchgranules; $e, g, h$, various Schizonnycetes; $f$ and $j$, fibres.

yeast plant; various species of Microcoicus, Leptothrix, and Bacillus, as well as the two minute green algæ described by Reinsch.

We presume, in the absence of definite statements, that the groups of organisms sketched in Fig. 2 were obtained at different times, and on different notes; otherwise the "flora" is indeed a rich and abundant one, and may probably have been an isolated one, to allow the species of Saccharomyces to form such a fine growth.

There is obviously a very serious side to all this, however, if further researches prove that, as appears possible, our most minute and dreaded enemies are always in our midst on such apparently welcome visitants as coin and bank-notes: money will have earned a worse name even than it has heretofore! En revanche, there are two points which no doubt will be insisted on: in the first place, the observers named have not, so far, described any organism on the money investigated which is known to be inimical to us ; and secondly, precautions have been taken from time immemorial against the transmission of currency passing from a plague-stricken community to a healthy one. Possibly the facts derived from these ob- servations will be made use of to bring more forcibly before the minds of our less careful brethren the dangers of handling "filthy lucre" in times of disease.

\section{STANDARD PITCH ${ }^{1}$}

$M$ SORET raises the question of musical pitch, and advocates A 432, long ago proposed by $M$. Meerens, of Belgium. It is rather curious that in Belgium itself M. Meerens's proposal was considered and rejected by a Commission appointed in 1877 , upon whose report the French pitch A 435 was adopted by Royal decree on March 19 of this year. There seems to be very little difference between the two; it amounts, in fact, to exactly I 2 cents or hundredths of an equal semitone, of which $21 \frac{1}{2}$ make a comma. Hence there is no practical reason for making the change as affecting singers. But no instruments made for A 435 would be available for A 432 , so that the advantage of uniformity would be lost, without any advantage to the voice or the quality of instruments. The arguments in its favour are almost entirely arithmetical. To begin with the inaudible I vibration and proceed by exact doubling to 64 is an arithmetical dream. It is true that König, by a most ingenious adaptation of a large tuning-fork acting in place of a pendulum to a clock going in a room at $20^{\circ} \mathrm{C}$. (for about five days in a year), has succeeded in making a fork of that precise number of vibrations at that precise temperature. But at $\mathrm{I} 5^{\circ} \mathrm{C}$., the temperature adopted for the French diapason normal (standard fork), the pitch of this would not be 64 , but, to take König's numbers, 64.036 . The charm of the arithmetic vanishes, therefore, with a slight alteration of temperature, and the pitch has become fully I cent (hundredth of a semitone) sharper. Granted that this is an imperceptible amount, yet it is enough to alter the whole of the arithmetic. Then the arithmetic is itself founded on just intonation, which is not adopted anywhere. If we take the equal temperament, now generally accepted, we should get for A $43^{2}$ the values C 256.9,

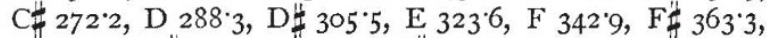

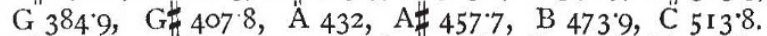
There is nothing charming here. M. Soret, in his table, quietly ignores the chromatic notes and the equal temperament. If, however, we took $\mathrm{C} 256$ as the startingpoint, the $\mathrm{A}$ of $\mathrm{C}$ major in just intonation would not be 432 , but, as he owns, a comma flatter, $426 \cdot 67$. He bases everything physically on the violin, which is tuned in D and not in $\mathrm{C}$, or the viola and violoncello, which are both tuned in $G$, not in $C$, and hence even for these instruments, with the great assumption of just intonation, his use of the major scale of $\mathrm{C}$ is incorrect. ${ }^{2}$ The reasons that are to guide us in the choice of a pitch must certainly not be arithmetical. For more than two centuries up to 1813 , when the Philharmonic Society was founded, all Europe used a pitch within a comma either way of Handel's fork A 422.5 . Then, owing to the presentation of new instruments by the Emperor of Russia to a Vienna regiment at the Congress of Vienna, pitch rose gradually but slowly. In 1826 our Philharmonic Society, under Sir G. Smart, adopted A 433, between M. Soret's and French pitch, and this was known for many years in London as the Philharmonic pitch. France adopted A 435 in 1859. Under Costa our pitch rose to its present height, A $454^{\circ} 7$. But our army pitch, used at Kneller Hall, and adopted for the forthcoming Exhibition, is A 452. Now, the trouble is that our classical composers wrote their music for Handel's pitch, while since i86o Continental composers

" J.-L. Soret, "Sur le Diapason" (Archives des Sciences physiques et naturelles. January, 1885. Geneva)

2 Savart, whom M. Soret quotes, was in error with regard to the pitch of the resonance of Cremona violins. It was not 256 vibrations. A series of instruments examined by Mr. A. J. Ellis in 1880 gave about 270 as the primary maximum, and 252 as the secondary. But the main character was the great uniformity of reinforcement for different pitches.-See his "History of Musical Pitch." 